\title{
Multicommutated Flow System for Spectrophotometric L(+)lactate Determination in Alcoholic Fermented Sugar Cane Juice Using Enzymatic Reaction
}

\author{
Eloisa A. Mocheuti Kronka ${ }^{a}$, Ana Paula S. Paim ${ }^{b}$, Cristiane A. Tumang ${ }^{c}$, Rodrigo Latanze ${ }^{a}$ and \\ Boaventura F. Reis ${ }^{*}$,
}

${ }^{a}$ Centro de Tecnologia e Desenvolvimento Agroindustrial, Universidade de Ribeirão Preto, Microdestilaria, Av. Costabile Romano, 2201, 14096-380 Ribeirão Preto - SP, Brazil

${ }^{b}$ Departamento de Hidráulica, Escola de Engenharia de São Carlos, Universidade de São Paulo, Av. Trabalhador Sãocarlense, 400, 13560-970 São Carlos - SP, Brazil

${ }^{c}$ Centro de Energia Nuclear na Agricultura, Universidade de São Paulo, Av. Centenário, 303, 1340-970 Piracicaba - SP, Brazil

\begin{abstract}
Neste trabalho foi desenvolvido um procedimento empregando multicomutação em fluxo e reação enzimática para determinação espectrofotométrica de $\mathrm{L}(+)$ lactato proveniente da fermentação alcoólica de vinho (mosto de cana de açúcar) O método espectrofotométrico foi baseado na reação com a enzima lactato oxidase, seguida pela reação com a enzima peroxidase e posterior condensação entre 4-clorofenol e 4 -aminoantipirina. O módulo de análise foi constituído por um conjunto de três válvulas solenóides, bomba peristáltica, espectrofotômetro e microcomputador equipado com interface de controle. Um programa escrito em QuickBASIC 4.5 foi desenvolvido para controlar as válvulas solenóides e realizar aquisição de dados. Amostras na faixa de concentração de 5,0 a $100,0 \mathrm{mg} \mathrm{L}^{-1}$ de $\mathrm{L}(+)$ lactato foram analisadas usando uma solução contendo 150 UI de lactato oxidase e 200 UI de peroxidase. Outras características analíticas tais como, desvio padrão relativo de $2 \%(\mathrm{n}=15)$ para uma amostra típica contendo $38,5 \mathrm{mg} \mathrm{L}^{-1} \mathrm{de} \mathrm{L}(+)$ lactato; freqüência de amostragem de 36 determinações por hora; e baixo consumo de reagentes $(1,0 \mu \mathrm{g}$ de 4 -clorofenol e $0,1 \mu \mathrm{g}$ 4-aminoantipirina) por determinação também foram obtidas.
\end{abstract}

A multicommutation flow system for the spectrophotometric determination of L(+)lactate in alcohol fermented sugar cane juice is proposed. The spectrophotometric method was based on the $\mathrm{L}(+)$ lactate conversion to pyruvate plus hydrogen peroxide by the lactate oxides enzyme, followed by reaction with peroxidase enzyme and condensation between 4-chlorophenol and 4-aminoantipyrine. The flow system network comprised three three-way solenoid valves controlled by a microcomputer that running a software wrote in Quick BASIC 4.5 provided also facilities to perform data acquisition. After optimization of system parameters, a set of alcohol fermented juice was analyzed to prove the procedure feasibility. Samples with concentration raging from 5.0 to $100.0 \mathrm{mg} \mathrm{L}^{-1} \mathrm{~L}(+)$ lactate were analyzed using a 150 UI lactate oxidize and 200 UI peroxidase enzymatic solution. Other advantageous features such as a relative standard deviation of $2 \%(\mathrm{n}=15)$ for a typical sample containing $38.5 \mathrm{mg} \mathrm{L}^{-1}$ $\mathrm{L}(+)$ lactate; an analytical throughput of 36 determination per hour; and a low reagent consumption $1.0 \mu \mathrm{g}$ 4-chlorophenol and $0.1 \mu \mathrm{g}$ 4-aminoantipyrine per determination were also achieved.

Keywords: L(+)lactate determination, multicommutation, sugar cane juice, enzymatic reaction

\section{Introduction}

In industrial plants that produce alcohol from sugar cane, contamination from microorganisms such as bacteria and leavening agents can occur resulting in lower product quality. The type of bacteria that contaminates this process

* e-mail: reis@cena.usp.br is generally fermentative and produces mainly organic acids. ${ }^{1}$ Contamination with Leuconostoc and Lactobacillus can occur during milling of sugar cane, which produces lactic acid during the fermentation process. Both stereoisomeric forms D(-) and L(+) of lactic acid has been found in the fermented product. ${ }^{2}$ The $\mathrm{D}(-)$ isomer is produced mainly during alcoholic fermentation. Its concentration is lower than that of the $\mathrm{L}(+)$ isomer, which 
is produced by decarboxylation of malic acid during malolactic fermentation. ${ }^{3}$ In this sense, determination of lactate acid during the fermentation stage allows detection of bacterial contamination and preventive action could be performed. Therefore, the availability of the analytical procedure that could be implemented in the industrial plants provided the results necessary to attain this requirement. This task could be easily carried out selecting an analytical procedure based on spectrophotometry.

The procedures for determination of $\mathrm{L}(+)$ lactate in alcohol fermented juice employing detection by spectrophotometry after enzymatic reaction has been used. ${ }^{3}$ The method is based on the reaction of $\mathrm{L}(+)$ lactate with the lactate dehydrogenase enzyme followed of spectrophotometric detection at $510 \mathrm{~nm}$ presenting as advantage the specificity due to lactate dehydrogenase enzyme (L-LDH). The enzymatic method based on lactate oxidase has been also used. ${ }^{4}$ The $\mathrm{L}(+)$ lactate is converted by the enzymatic reaction to pyruvate plus hydrogen peroxide followed of reaction with peroxidase and condensation between 4-chlorophenol and 4-aminoantipyrine and detection by spectrophotometry at $510 \mathrm{~nm}$.

The manual procedure is very laborious and its reagent consumption is high presenting also contamination risk that can be amplified when involving microorganisms. In this sense, an automated procedure employing multicommutation flow analysis should be recommended considering that it is a closed system, thus minimizing the risk of sample contamination. ${ }^{5-7}$ The flow system manifold based on multicommutation presents as advantages ability to handle several solutions using a single pumping channel, low reagent consumption and facility for automation using not expensive equipment. ${ }^{8,9}$

Considering the comments pointed out above, in this work one intend to develop an automated procedure for the determination of lactate in fermented sugar cane juice using lactate oxidase reaction and spectrophotometric detection. ${ }^{5}$ The procedure will be implemented employing a flow manifold designed to implement multicommutation and binary sampling approach. ${ }^{9,10}$

\section{Experimental}

\section{Apparatus}

The equipment set up comprised of a mp4 Ismatec peristaltic pump equipped with Tygon pumping tube; a 432 Femto spectrophotometer equipped with a flow cell, $100 \mu \mathrm{L}$ inner volume, $10 \mathrm{~mm}$ optical path; three $161 \mathrm{~T} 031$ Nresearch 3-way solenoid valves, a microcomputer furnished with a PCL771S Advantech interface card; a regulated $12 \mathrm{~V}$ power supply for the solenoid valves; reaction coil and flow lines of polyethylene tubing $0.8 \mathrm{~mm}$ i.d.; joint devices machined in acrylic; and a gas bubble removing chamber tailor-made in glass with $80 \mathrm{~mL}$ inner volume.

\section{Reagents and solutions}

All chemicals were analytical grade. Purified water (conductivity less than $0.1 \mu \mathrm{S} \mathrm{cm}^{-1}$ ) obtained with a MilleQ system was used throughout. A $0.2 \mathrm{~mol} \mathrm{~L}^{-1}$ tris (hydroxymethyl aminomethane) buffer solution was prepared by dissolving $24.2 \mathrm{~g}$ of salt in $1000 \mathrm{~mL}$ of water. After dissolution the $\mathrm{pH}$ was adjusted to 6.5 with a $1 \mathrm{~mol} \mathrm{~L}^{-1}$ hydrochloric acid solution. A $5.4 \mathrm{mmol} \mathrm{L}^{-1}$ 4-chlorophenol plus $0.4 \mathrm{mmol} \mathrm{L}^{-1} 4$-aminoantipyrine solution was prepared by dissolving $0.1736 \mathrm{~g}$ of 4-chlorophenol and $0.02 \mathrm{~g}$ of 4-aminoantipyrine in $250 \mathrm{~mL}$ of tris buffer solution (described above). A $1000 \mathrm{mg} \mathrm{L}^{-1}$ lactate stock solution was prepared by dissolving $1.0779 \mathrm{~g}$ lithium lactate salt in $1000 \mathrm{~mL}$ of water. Working solutions $0.0,10.0,25.0,50.0$, 75.0 and $100.0 \mathrm{mg} \mathrm{L}^{-1}$ were prepared by appropriated dilution from the stock solution with water. These solutions were prepared daily. A 150 UI lactate oxidase enzyme solution plus 200 UI peroxidase enzyme (from Aldrich Sigma) was prepared daily by diluting to $100 \mathrm{~mL}$ with the $0.2 \mathrm{~mol} \mathrm{~L}^{-1}$ tris buffer solution.

The samples extracts were prepared by taking $20 \mathrm{~mL}$ of alcohol fermented sugar cane juice that was stirred for $10 \mathrm{~min}$. After separation of solid phase via centrifugation, the supernatant was collected and stored in a polyethylene bottle at $6{ }^{\circ} \mathrm{C}$. Before use, the sample extract was reequilibrated to laboratory temperature $\left(25^{\circ} \mathrm{C}\right)$.

\section{Procedure}

The system manifold was designed to implement the analytical procedures based on multicommutation and binary sampling approach ${ }^{6,11}$ and its flow diagram is depicted in Figure 1. In this configuration all valves are switched off and the carrier solution (Cs) is flowing through valve $\mathrm{V}_{1}$ towards the detector (DET).

The system worked with solutions flowing by suction, thus the inner pressure was lower than that of atmosphere and gas dissolved in the solutions could be delivered forming little bubbles, which could attain the flow cell of the spectrophotometer impairing the precision of the measurements. Therefore, aiming the prevention of this effect the gas bubble-removing chamber (G) was coupled to the system network $3 \mathrm{~cm}$ distal of the flow cell inlet.

When the microcomputer ran the software to start the 

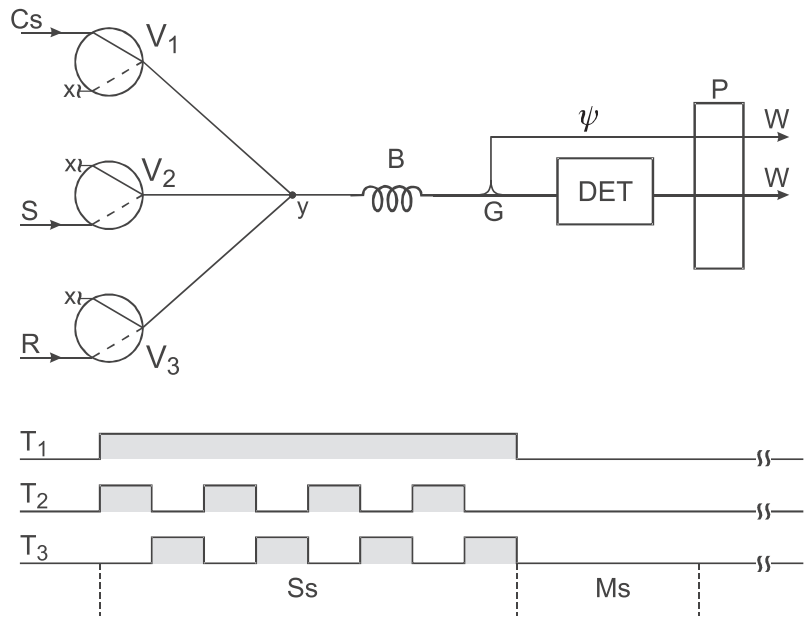

Figure 1. Flow diagram of the system: $V_{1}, V_{2}$ and $V_{3}=$ three-way solenoid valves; $\mathrm{y}=$ joint device machined in acrylic; $\mathrm{B}=$ reaction coil, $100 \mathrm{~cm}$ length, $0.8 \mathrm{~mm}$ inner diameter; $\mathrm{G}=$ debubble chamber, inner volume $80 \mu \mathrm{L}$; DET $=$ spectrophotometer detector at $510 \mathrm{~nm}$; $\mathrm{P}=$ peristaltic pump; $\mathrm{C}_{\mathrm{s}}=0.2 \mathrm{~mol} \mathrm{~L}^{-1}$ tris buffer solution, flow rate at $33 \mu \mathrm{L} \mathrm{s}^{-1} ; \mathrm{S}=$ sample; $\mathrm{R}=$ enzymatic and chromogenic solution; $\mathrm{y}=$ gas bubble removing channel, flow rate at $10 \mu \mathrm{L} \mathrm{s}^{-1} ; \mathrm{W}=$ waste. The solid and dashed lines into the valves symbols indicated the flow pathway when valves were switched on and off, respectively. $T_{1}, T_{2}$ and $\mathrm{T}_{3}=$ valves $\mathrm{V}_{1}, \mathrm{~V}_{2}$ and $\mathrm{V}_{3}$ timing course valves, respectively; Ss and Ms = sampling and measuring steps, respectively. The shadow surfaces indicated that the related valve was switched on.

sampling stage (Ss), a set of electric pulses was sent through the PCL711S interface card to switch on/off valves $\mathrm{V}_{2}$ and $\mathrm{V}_{3}$ alternately maintaining valve $\mathrm{V}_{1}$ switched on. Under this operational condition, the carrier stream (Cs) was halted and reaction coil (B) was loaded with a string comprised by sample slugs in tandem with slugs of reagent enzymatic solution ( $R$ ). As indicated in the valves timing time course $\left(\mathrm{T}_{1}, \mathrm{~T}_{2}, \mathrm{~T}_{3}\right)$, after ending the sampling step, all valves were switched off and the carrier solution (Cs) flowed again through the reaction coil directing the sample zone towards the detector (DET). While the sample zone was displaced through the reaction coil (B), dispersion between solution slugs occurred permitting development of the chemical reaction.

After ending the sampling stage (Ss) the microcomputer waited a time interval of $10 \mathrm{~s}$, then it sent through the serial interface a stopping command to peristaltic pump. After the time delay (Ms), which was settled to permit the progress of the enzymatic reaction, the pumping condition was established again. The measurement stage (Ms) was carried out while sample zone was stopped into the flow cell. The signal was read by the microcomputer through the analog input of the PCL711S interface card that was coupled to the spectrophotometer output. The data was saved as an ASCII file to permit further processing. While the measurement was run, a plot of the signals was displayed on the computer screen as a function of time to allow its visualization in real time.

Preliminary assays were carried out to optimize the ratio between sample slug volume and enzymatic solution. These studies were done switching on valve $\mathrm{V}_{3}$ for $0.4 \mathrm{~s}$ and varying the time interval to switch on valve $V_{2}$ from 0.2 to $0.8 \mathrm{~s}$. These tests showed that better result was obtained when the $\mathrm{V}_{2} / \mathrm{V}_{3}$ time ratio was $0.2 / 0.4$. This setting was maintained to perform the further experiments.

The $\mathrm{V}_{2}$ and $\mathrm{V}_{3}$ switching step on can be repeated several times to change the volume of sample string and henceforth it is referred as sampling cycle. In the flow procedure, the signal magnitude can vary with sample volume, and in this work its optimization was achieved by varying the sampling cycle number from 2 to 12 . Hence enzymatic reaction presented slow kinetic some assays were carried out using a stopped flow strategy to define the time interval that could be employed in order to obtain to optimize sensitivity and throughput. The microcomputer performed this task by sending a control command to the peristaltic pump through the serial interface to stop its rotation during a time interval (Ms) previously settled.

After establishing the optimal operational condition complementary assays were carried out to verify the linear response range and the long-term stability using standard solutions. After samples of alcohol fermented juice were processed aiming to demonstrate the system suitability.

\section{Results and Discussion}

As depicted in the valves timing course (Figure 1) solenoid valves $\mathrm{V}_{2}$ and $\mathrm{V}_{2}$ were switched on/off alternately, therefore slugs of sample and enzymatic solutions were inserted in tandem into the reaction coil that is a feature due to binary sampling approach. ${ }^{6-8}$ In this sense, the volumes of the solutions slugs affect the mixing between sample and reagent solutions. The time intervals of $0.2 \mathrm{~s}$ and $0.4 \mathrm{~s}$ were settled to switch on valves $\mathrm{V}_{2}$ and $\mathrm{V}_{3}$ (Figure 1), respectively. The sampling flow rate was $33 \mu \mathrm{L} \mathrm{s}^{-1}$, therefore the slugs volumes were $6.4 \mu \mathrm{L}$ and $12.8 \mu \mathrm{L}$ for sample and enzymatic solutions, respectively. The inner diameter of the reaction coil was $0.8 \mathrm{~mm}$, thus its cross section was $0.5 \mathrm{~mm}^{2}$. Each slug of sample solution initially extended into $12.8 \mathrm{~mm}$ of the reaction coil (B) and the dimension of the enzymatic solution slug was tow-fold. This fact could impair an even mixture of sample and reagent solutions when volumes of slugs were higher than the selected values $(6.4 \mu \mathrm{L}$ and 12.8 $\mu \mathrm{L}$ ), thus resulting as a consequence the records of the signals presenting not smoothed profiles.

The dispersion effect of the sample zone into carrier solution can be controlled adjusting the volume of the 
sample zone. To do this in the usual flow system the sampling loop must be changed, therefore with the proposed system, this task was easily carried out varying the number of sampling cycles. Considering the expected concentration of the analyte, 10 sampling cycles were selected. Whole volumes of sample and enzymatic solutions were 64 and $128 \mu \mathrm{L}$, respectively. The initial total volume of sample zone was $192 \mu \mathrm{L}$ corresponding to $20 \%$ of reaction coil volume. Under this condition, the volume of sample zone could be increased in order to minimize sample dispersion to improve sensitivity.

In the usual flow system, the time interval to permit the chemical reaction development is dependent of both carrier stream flow rate and length of reaction coil. In the propose manifold (Figure 1), the inner volume of the reaction coil was $500 \mu \mathrm{L}$ and flow rate was $33.3 \mu \mathrm{L} \mathrm{s}^{-1}$, therefore the sample residence time was approximately $15 \mathrm{~s}$ (time interval to displace the first portion of the sample zone from the coil inlet (joint point $y$, Figure 1) up to the detector. Hence the kinetic of the enzymatic reaction was slow this time interval was not enough to assure good measurements. To surpass this difficulty, a stopped flow stage was implemented yielding the results used to plot the curve of Figure 2, where one can observe that the signals increased, practically, linear with the reaction time. The behavior of this curve indicates that the progress of the reaction does not tend toward equilibrium condition, therefore if high sensitivity was required, the time interval settled to perform the measurement stage (see Figure 1) should be increased. In this work, considering the lactate concentration usually found in alcoholic fermented juice, the measurement time interval (Ms) was maintained at $45 \mathrm{~s}$.

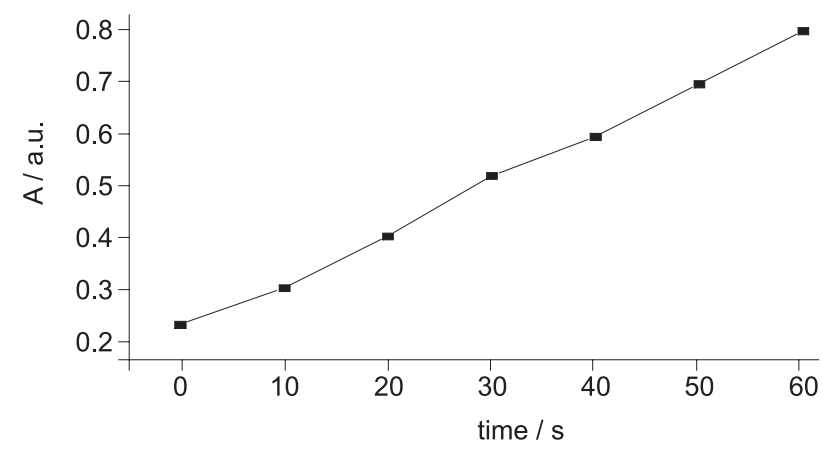

Figure 2. Effect of the reaction time on signal measurement: $\mathrm{A}=$ absorbance. Assay carried out using a $100 \mathrm{mg} \mathrm{L}^{-1} \mathrm{~L}(+)$ lactate solution and performing ten analytical cycles comprising each one 13.2 and $6.6 \mu \mathrm{L}$ of sample and reagent solutions, respectively.

After establishing the operational condition the procedure was applied for the determination of lactate in alcohol fermented juice of sugar cane and results are shown in Table 1. Accuracy was assessed applying the paired $t$-test with results obtained using a reference method (Sigma enzymatic kit) and no significance difference at $95 \%$ confidence level was observed. Other advantageous features such as a linear response ranging from 5.0 to $100 \mathrm{mg} \mathrm{L}^{-1}$ $\mathrm{L}(+)$ lactate $(\mathrm{r}=0.998)$; a relative standard deviation of $2.0 \%$ $(\mathrm{n}=15)$ for a typical sample containing $38.5 \mathrm{mg} \mathrm{L}^{-1}$ $\mathrm{L}(+)$ lactate; a sampling rate of 36 determination per hour; and a low reagent consumption $1.0 \mathrm{mg}$ 4-chlorophenol and $0.1 \mathrm{mg}$ 4-aminoantipyrine per determination were also achieved.

Table 1. Results of $\mathrm{L}(+)$ lactate determination in fermented sugar cane juice

\begin{tabular}{ccc}
\hline Samples & $\begin{array}{c}\text { Proposed method } \\
\left(\mathrm{mg} \mathrm{L}^{-1}\right)\end{array}$ & $\begin{array}{c}\text { Enzymatic kit } \\
\left(\mathrm{mg} \mathrm{L}^{-1}\right)\end{array}$ \\
\hline 1 & $47.8 \pm 0.7$ & $48.5 \pm 0.5$ \\
2 & $38.5 \pm 0.8$ & $37.9 \pm 0.3$ \\
3 & $33.6 \pm 0.8$ & $35.3 \pm 0.6$ \\
4 & $50.1 \pm 1.1$ & $48.2 \pm 0.9$ \\
5 & $37.2 \pm 0.6$ & $36.1 \pm 1.2$ \\
\hline
\end{tabular}

Results average of three consecutive measurements and standard deviation.

\section{Acknowledgments}

The authors are greatful to FAPESP and CNPq.

\section{References}

1. Stupiello, M.G.; Horii, J.; Stab Açúcar, Àlcool e Subprodutos, $\mathrm{N}^{\circ} .17,1981$.

2. Macmaster, L. M.; Ravno, A.B.; Congress of the International Society of Sugar Cane Technologists, 16., S. Paulo, 1977.

3. Araújo, A.N.; Lima, J.L.F.C.; Saraiva, M.L.; Zagatto, E.A.G.; Am. J. Vitic. 1997, 48, 428.

4. Tumang A.C.; Borges E.P.; Reis B.F.; Anal. Chim. Acta 2001, 438, 75.

5. Rocha, F.R.P.; Martelli, P.B.; Reis, B.F.; J. Braz. Chem. Soc. 2004, 15, 38.

6. Tumang, C. A.; Luca, G. C.; Fernandes, R. N.; Reis, B. F.; Krug, F. J.; Anal. Chim. Acta 1998, 374, 53.

7. Vieira, J. A.; Raimundo, I. M.; Reis, B.F.; J. Braz. Chem. Soc. 2003, 14, 259.

8. Kronka, E.A.M.; Borges P.R.; Latanze R.; Paim A.P.S.; Reis B.F.; J. Flow Injection Anal. 2001, 18, 132.

9. Borges, E. P.; Martelli, P.B.; Reis, B. F.; Mikrochim. Acta 2000, 135, 179.

10. Fernandes, R. N.; Reis, B. F.; Campos, L. F. P.; J. Auto. Met. Manage. Chem. 2003, 25, 1.

Received: April 24, 2003

Published on the web: December 16, 2004

FAPESP helped in meeting the publication costs of this article. 